$\stackrel{\odot}{\text { III }}$

\title{
TOŻSAMOŚĆ JEDNOSTKI W OBLICZU WYZWAŃ WIELOKULTUROWEGO SPOŁECZEŃSTWA
}

\begin{abstract}
Tomasz Leszniewski, Tożsamość jednostki w obliczu wyzwań wielokulturowego społeczeństwa [Individual's Identity of the Facing the Challenges of Multicultural Society] edited by E. Smolarkiewicz, J. Kubera „,CZłowiek i Społeczeństwo"vol. XLIV: Tożsamośći identyfikacje. Propozycje teoretyczne - doświadczenia badawcze [Identity and identifications. Theoretical proposals - research experiences], Poznań 2017, pp. 65-79, Adam Mickiewicz University. Faculty of Social Sciences Press. ISSN 0239-3271.
\end{abstract}

This paper is a attempt of reflection concerning of appearing human identity problems which take a place in differential and complex society. A special attention was paid nationality identification. Using the concept of G.H. Mead and J. Habermas describe the complex structure of an individual's identity, presenting various forms of social relationships that connect people with others and try to explain the problem of exclusion and hostility towards others/strange in the perspective of identity. The key issue in this social relationship is the connection the individual and the collective dimension of human identity. The basic hypothesis of the text assumes that the more the community limits the development of a person's (individual) identity, the more likely he becomes vulnerable to feelings of threat and hostility towards another.

Tomasz Leszniewski, Uniwersytet Mikołaja Kopernika w Toruniu, Wydział Nauk Pedagogicznych, Katedra Socjologii Edukacji i Pedagogiki Społecznej, ul. Lwowska 1, 87-100 Toruń, tomaszl@umk.pl

\section{Wstęp}

Obecne warunki życia i rozwoju człowieka charakteryzujące się wzrostem złożoności i wewnętrznej zależności elementów wyznaczających przestrzeń życiową, powodowane globalnymi przeobrażeniami, przywołują powracające w takich momentach historii zasadnicze pytanie o kondycję jednostki. 
Społeczny świat bowiem w każdym ze swych wymiarów: komunikacyjnym, organizacyjno-instytucjonalnym, kulturowym, ekonomicznym, itd. zyskuje źródła energii oraz zasoby informacji ${ }^{1}$ będące impulsem postępujących zmian skutkujących coraz większym wewnętrznym zróżnicowaniem systemów społecznych oraz poszerzaniem ich granic. W jaki sposób oraz w jakim stopniu reorganizacja środowiska społecznego i porządkujących go reguł znajduje swe odzwierciedlenie na poziomie jednostkowym, w postaci zmieniających się ludzkich tożsamości?

Nieliniowość procesu zmian społecznych sugeruje brak prostego przełożenia zasad organizacyjnych występujących w wymiarze życia zbiorowego na poziom jednostkowy jako ich wierne lustrzane odbicie. Dynamika postępujących przemian opiera się zarówno na aktywności czynników sprawczych, jak i działań wyrażających opór, czy wręcz sprzeciw, mający wygenerować alternatywny porządek społeczny. Dopiero ta dialektyczna relacja pozwala na zrozumienie wyłaniającej się rzeczywistości społecznej, włącznie z procesami tożsamościowymi przebiegającymi w tych okolicznościach. Jak pisze Manuel Castells (2009: 41), „,wiek globalizacji jest również wiekiem odrodzenia nacjonalizmu, wyrażającym się zarówno w zakwestionowaniu istniejących państw narodowych, jak i w rozpowszechnionym (re) konstruowaniu tożsamości na podstawie narodowości, zawsze afirmowanej przeciwko obcym. Ten historyczny trend zaskoczył niektórych obserwatorów, szczególnie po tym, jak trzykroć głoszono śmierć nacjonalizmu: za sprawą globalizacji gospodarki i internalizacji instytucji politycznych, uniwersalizmu kultury, powszechnie podzielanej i transmitowanej przez media elektroniczne, edukację, piśmiennictwo, urbanizację i modernizację oraz za sprawą ataku naukowców na samo pojęcie narodu”.

Castells opisuje więc napięcie między rzeczywistością społeczną, która staje się coraz bardziej zróżnicowana i złożona, a reakcjami na ten stan rzeczy określonych grup społecznych czy jednostek. Związane to jest z faktem, że w obrębie struktury tożsamościowej człowieka dochodzi do rekonstrukcji wewnętrznych relacji między identyfikacjami grupowymi oraz wzrostu liczebności płaszczyzn, w ramach których utożsamianie następuje. Ze względu na znaczące różnice aksjologiczne poszczególnych punktów odniesienia generujących określony rodzaj identyfikacji możemy mówić o szeroko rozumianym zjawisku wielokulturowości, które stanowi podstawową przestrzeń ludzkiej egzystencji w wymiarze społecznym.

1 Jest to nawiązanie do Parsonsowskiej koncepcji zmiany w ramach systemu społecznego (Parsons 2009). 
Powyższe słowa socjologicznej diagnozy dotyczące kondycji współczesnego społeczeństwa, obecne w naukowym dyskursie, skłaniają do postawienia kluczowych pytań dotyczących ludzkiej tożsamości. Interesuje nas mianowicie, w jaki sposób przebiega proces konstruowania tożsamości człowieka w rzeczywistości tak zmiennej i zróżnicowanej. Jak wyglądają relacje między różnymi identyfikacjami społecznymi w obrębie wewnętrznej struktury tożsamości oraz jak zrozumieć siłę dominacji jednej kategorii społecznej (np. związanej z przynależnością do grupy narodowej czy etnicznej) w formowaniu tożsamości osoby? Pytania te będą wyznaczać kierunek dalszej refleksji podjętej w tym artykule.

\section{Tożsamość w obliczu innego}

Sięgając do socjologicznej tradycji interakcyjnej, możemy przywołać podstawowe założenia związane z rolą Innego w procesie konturowania ludzkiej tożsamości oraz moralnego rozwoju człowieka. Otóż zarówno w kontekście ontogenetycznym, jak i filogenetycznym kluczową rolę w rozwoju jednostki odgrywa Inny oraz powstająca w tych warunkach relacja wymagająca interakcyjnego współdziałania. Założenie George’a Herberta Meada o pierwszeństwie organizacji społecznej względem ludzkiego umysłu podkreśla interakcyjne korzenie tego drugiego. „Umysł jest tylko wprowadzeniem tego zewnętrznego procesu do postępowania jednostki, aby mogła ona stawić czoło stającym przed nią problemom” (Mead 1975: 262). Dzięki trwałemu charakterowi relacji łączących jednostkę z otoczeniem społecznym, czyli z innym człowiekiem, możliwe staje się zatem doświadczenie samego siebie. „Jednostka doświadcza siebie samej jako takiej nie bezpośrednio, lecz tylko pośrednio, przyjmując punkt widzenia innych członków tej samej grupy społecznej lub uogólniony punkt widzenia grupy społecznej, do której należy. [...] Występowanie osobowości zawsze zakłada doświadczenie innego; osobowość nie mogłaby doświadczyć sama siebie” (Mead 1975: 193, 271). Osoba w relacjach społecznych, podejmując się współpracy, uczestniczy w komunikacji wymagającej zdolności do symbolicznego postrzegania i wyrażania przeżywanej rzeczywistości. Daje jej to możliwość stawania się dla siebie samej przedmiotem poznania. Zasadniczy na drodze ludzkiego rozwoju i uspołecznienia zarazem jest proces przyjmowania roli Innego. Umiejętność ta stanowi podstawę zaistnienia jaźni człowieka, która pozwala na intersubiektywny stosunek do własnej osoby. Jednostka posługująca się jaźnią ma możliwość występowania równocześnie w roli poznającego 
podmiotu, jak i poznawanego przedmiotu. Staje się więc sama dla siebie przedmiotem poznania, analogicznie jak poznawany jest każdy element świata zewnętrznego. W tego typu działaniu wyraża się zdolność osoby do bycia kilkoma rzeczami równocześnie, jak wskazuje Mead, analizując proces uspołecznienia (Mead 1932: 49). Można to odnieść zarówno do funkcjonowania w roli - i przyjmowania roli innego, jak i do kontekstu czasowego, w ramach którego w obliczu potrzeby teraźniejszego działania dochodzi do relacji między przeszłym doświadczeniem a przyszłym oczekiwanym stanem.

Koniecznym atrybutem na drodze rozwoju jest zdolność człowieka do bycia świadomym własnego istnienia oraz odrębności względem otaczającego świata. Poczucie własnej tożsamości musi być zapośredniczone przez akt określenia granicy odcinającej ,ja” od „nie-ja” osoby. Samoświadomość, jak pisze Mead (1975: 236-237), ,jest tworzona przez przyjmowanie lub odczuwanie postawy innego w stosunku do siebie, a nie przez doznawanie lub percepcję prostych doznań osobistych. Aż do chwili powstania samoświadomości jednostka doświadcza swego ciała (jego uczuć i doznań) jako jedynie bezpośredniej części swego środowiska, nie jako czegoś własnego, nie w kategoriach samoświadomości. Najpierw musi powstać osobowość i samoświadomość i dopiero wtedy doświadczenia mogą być identyfikowane z osobowością lub przez nią przywłaszczane”. Oznacza to, że podstawowym narzędziem rozwoju człowieka, jego samoświadomości i osobowości jest bez wątpienia, zdaniem Meada, relacja powstająca między jednostką a Innym. Ta przestrzeń interakcyjna oraz zdolność komunikacji człowieka ze światem, a także z samym sobą, w konsekwencji prowadzą nie tylko do pojawiania się kompetencji adaptacyjnych, ale również osobowej tożsamości. Jednostka ma możliwość rozwijania własnej tożsamości poprzez wewnętrzny dialog dokonujący się między różnymi fazami jaźni ( $I$ - ja podmiotowe oraz $M e$ - ja przedmiotowe) odnoszącymi się do tego, co jednostkowe i społeczne. Uwewnętrznienie Innego czyni tożsamość człowieka czymś refleksyjnym i dynamicznie zmiennym. Jej dialogiczna struktura wyrasta z pierwotnych relacji ze środowiskiem społecznym i powoduje, że „człowiek staje się pełniejszy, im bardziej rozpoznać się może w oczach innych” (Koczanowicz 1992: 39).

Refleksyjność i inteligencja, jako niezbędne przymioty człowieka wykorzystywane w procesie tworzenia własnej tożsamości, ze swej natury, jak zauważa Mead, są interakcyjne. Pierwszy z nich stanowi wyraz samoświadomości człowieka oraz jego zdolności do symbolicznego doświadczania rzeczywistości. Tylko wówczas między „mową” (symbolicznym wyrazem działania) a „ręką” (działaniem) możliwe staje się pojawienie fazy namysłu, będącej efektem zawieszenia na moment realizowanych czynności. 
„Dla pełnego rozwoju inteligencji konieczne jest istnienie samoświadomości; ale trzeba, by była jakaś faza działania, która zatrzymuje się przed jego realizacją, jeżeli to działanie ma się rozwijać inteligentnie” (Mead 1975: 328-329). Drugi z wyżej wskazanych przymiotów staje się zatem efektem posługiwania się zdolnością refleksyjności przez jednostkę, będąc zarazem przejawem faktu zinternalizowania konwersacji dokonującej się na podstawie znaczących gestów (Mead 1975: 266).

Należy także zwrócić uwagę, że nie tylko wymiar kognitywny winien być uwzględniony w kontekście konstruowania ludzkiej tożsamości w relacji z innym człowiekiem, ale również wymiar emocjonalny. Stanowi on bowiem istotny czynnik motywacyjny w działaniach jednostki. Pozwala skanalizować ludzką energię na społeczny aspekt jej egzystencji. Jak wskazuje George Cooley (Mucha 1992: 181), „emocja odnosząca się do siebie samego może być uważana za instynktowną i bez wątpienia rozwinęła się w związku ze swą ważną funkcją polegającą na stymulowaniu i ujednolicaniu szczególnych działań jednostek”. Oznacza to, że społeczny kontekst ludzkiej aktywności wskazuje silny związek symbolicznego znaczenia z emocjonalnym pobudzeniem. Jednostka wykonuje daną czynność ze względu na emocjonalną potrzebę wyrażania swojej odrębności, używając celów i środków ważnych z perspektywy środowiska społecznego. Innymi słowy, wchodzenie w relacje społeczne przez osobę powodowane jest chęcią coraz pełniejszego samookreślenia poprzez „zawłaszczanie” zarówno w wymiarze symbolicznym, jak i materialnym, którego cele określa kultura grupy przynależenia i/bądź odniesienia. Jak pisze dalej Cooley, te cele, idee odnoszą się przede wszystkim do wykonywania władzy i własnej sprawczości, a zatem do tego, co podstawowe w budowaniu własnej tożsamości. Wiąże się to mianowicie z koniecznością wyodrębnienia własnej osoby ze środowiska - naturalnego i społecznego - poprzez ustalenie czytelnych granic wyrażających opozycyjność między „ja” i „nie-ja” (Mucha 1992: 185).

To kognitywno-emocjonalne związanie dotyczące tożsamości człowieka wyraża się szczególnie w koncepcji jaźni, która zdaniem Cooleya ma charakter odzwierciedlony. Jest ona odbiciem w osobie innego i powracającym poczuciem własnej odrębności i wyjątkowości względem otaczającego świata. Otóż ten typ jaźni składa się z trzech zasadniczych elementów, tj. (1) z naszego wyobrażenia, jak się prezentujemy innej osobie, (2) z naszego wyobrażenia dotyczącego sądów Innego na temat naszej osoby na podstawie wcześniejszego elementu prezentacji oraz (3) z rodzaju uczucia, które poprzednie elementy powodują (np. dumy, zadowolenia bądź wstydu, upokorzenia itp.) (Mucha 1992: 189). 
Podsumowując powyższą refleksję dotyczącą teoretycznych uzasadnień interakcyjnej natury tożsamości człowieka, w której powstawaniu, bez wątpienia, jedną z najważniejszych ról odgrywa Inny, należałoby postawić kilka pytań wyrażających pewne wątpliwości związane z podjętym tematem, a mianowicie: czy każdy Inny jest dla człowieka „bodźcem” stymulującym rozwój? Dlaczego i jak różnicujemy ludzi na swoich i obcych? Co się dzieje z ludzką tożsamością w sytuacji „krzyżowania się kręgów społecznych”, kiedy pojawia się problem wielokulturowości środowisk? Dlaczego tak istotną rolę w strukturze tożsamościowej człowieka odgrywa identyfikacja z narodem czy grupą etniczną? Co może stanowić przyczynę nacjonalistycznych ${ }^{2}$ postaw na płaszczyźnie tożsamościowej? Pytania te zdają się zarówno szczególnie istotne, jak i zdecydowanie aktualne, co powoduje, że nie sposób je pominąć w socjologicznym namyśle nad bieżącymi problemami dotyczącymi współczesnego człowieka i jego tożsamości - zwłaszcza w obliczu świata, który staje się coraz bardziej dynamiczny, zmienny i wewnętrznie zróżnicowany.

\section{Inny - swój czy obcy?}

W interakcyjnym podejściu do świata społecznego i rozwoju człowieka, ale także w potocznym doświadczeniu jednostki trudno zakwestionować szczególną rolę Innego oraz wręcz konieczność jego obecności w naszym doświadczaniu siebie. Nawiązując do cytowanego wcześniej Meada, możemy przywołać kategorię rozs zerzonego doświadczenia, która skojarzona jest ze zdolnością osoby do poszerzania swoich kontaktów społecznych poprzez metodę identyfikacji siebie ze wszystkimi ludźmi. Pozwala to na przełamanie wszystkich barier społecznych i generuje „powódź emocji, ponieważ uwalnia nieskończoną liczbę kontaktów z innymi ludźmi, które do tej pory były stłumione, zahamowane. W wyniku wkroczenia jednostki do tej nowej społeczności, stanie się członkiem, wartość należąca do wszystkich członków tej grupy stała się także jej własnością” (Mead 1975: 304). Jak zatem dochodzi do sytuacji, kiedy to inny człowiek staje się kimś nie tylko nieistotnym z perspektywy naszego życia i rozwoju, ale wręcz osobą,

${ }^{2}$ Wykorzystane w tekście pojęcie nacjonalizmu jest skojarzone z ideologicznym nastawieniem do przedstawicieli innych grup, chrakteryzującym się dążeniem do wewnętrznej unifikacji aksjonormatywnej (homogeniczności) oraz silnym wykluczaniem inności, włącznie z jej dewaluacją. Dobrze oddaje to użyte przez Jerzego Szackiego pojęcie nacjonalizmu integralnego (Kwaśniewicz 1999: 283). 
która stanowi zagrożenie. W konsekwencji proces rozszerzania własnego doświadczenia przez jednostkę tej osoby nie obejmuje. Być może należy uznać, że fakt obcości i wrogości zarazem wobec owych innych jest ubocznym skutkiem procesu konstruowania ludzkiej tożsamości.

Nawiązując do socjologicznej tradycji wyjaśniającej zjawisko obcości, którą zawdzięczamy refleksji Georga Simmla (2005), należy uznać, że jest ona typem relacji opartej na „swoistym połączeniu bliskości i dystansu, obojętności i zaangażowania. [...] Jedność bliskości i dystansu, zawarta w każdym stosunku międzyludzkim, w tym przypadku ulega pewnej modyfikacji, którą można najkrócej sformułować następująco: oddalenie w obrębie stosunku oznacza, że osoba bliska jest daleko, obcość zaś, że blisko jest osoba daleka” (Simmel 2005: 300). Ten sposób postrzegania problemu obcego i obcości w kontekście tworzenia ludzkiej tożsamości zwraca szczególną uwagę na wymiar porządkowania przestrzeni i związanego z nią ruchu. Owa zmienność w wymiarze przestrzennym oddziałuje na charakter relacji międzyludzkiej oraz na lokalizację granic społecznego świata, w ramach którego dochodzi do podziałów na swoich i obcych. Według Simmla obcość wynika z tego, że inny jest przez nas doświadczany jako osoba o abstrakcyjnej naturze. Oznacza to, iż „w stosunkach z obcym owe cechy powszechne odgrywają niepomiernie większą rolę niż cechy indywidualne, właściwe tylko uczestnikom danego stosunku. Obcy jest nam bliski o tyle, o ile odczuwamy wspólne nam i jemu podobieństwo cech narodowych, społecznych, zawodowych czy też ogólnoludzkich. Natomiast jest nam daleki o tyle, o ile te wspólne cechy nie obejmują tylko nas, o ile wiążą nas tylko dlatego, że w ogóle wiążą bardzo wielu” (Simmel 2005: 303).

Wnioski, które się w tym momencie nasuwają, wskazują na szczególną rolę w procesie czynienia z Innego obcego identyfikacji zbiorowej. Tożsamość społeczna (kolektywna), a nie indywidualna, w tej sytuacji określa charakter międzyludzkich relacji. Tym samym jednak zjawisko to wskazuje na źródło problemu wykluczania inności (obcego): przyczyną jest mianowicie to, że między jednostką a obcym tworzy się relacja oparta na swoistym związku tożsamości społecznych, niejako z pominięciem czy ograniczeniem roli tożsamości osobowej (indywidualnej). Posługiwanie się kategoryzacją społeczną wyznaczającą grupowe podziały sprawia, że ów Inny postrzegany przez pryzmat abstrakcyjnych właściwości przestaje być powodem zawiązywania relacji społecznych. Abstrakcyjność bowiem pozbawia go wyjątkowości, a tym samym szczególnego znaczenia, co prowadzi do utraty poczucia „wewnętrznej konieczności” istnienia tego stosunku (Simmel 2005: 303). Postrzeganie Innego w kategoriach abstrakcyjnych właściwości wynikających 
ze społecznych podziałów, co związane jest ze swoistą dominacją w strukturze tożsamościowej wymiaru kolektywnego, sprawia zatem, że ów Inny wraz z jego światem nie stanowi istotnego elementu na drodze „poszerzania doświadczenia”, kojarzonego z procesem jednostkowego rozwoju.

Należy jednak zwrócić uwagę, że w Simmlowskich rozważaniach na temat obcego występują dwa typy relacji. Jeden traktuje obcość i stosunek do niej w kategoriach pozytywnych, tzn. pozbawionego wrogości i negatywnego wartościowania. Jest jeszcze jeden typ, któremu, niestety, Simmel nie poświęca wiele uwagi, uznając, że wykracza poza przedmiot zawartych w tekście rozważań. Jest to mianowicie sytuacja, „kiedy odmawia się innym tych ogólnych właściwości, które uważa się za specyficznie ludzkie. Wówczas [...] stosunek do innych polega właśnie na braku stosunku” (Simmel 2005: 304). Pozwala to wnioskować, że relacja z Innym (obcym) może mieć dynamiczny charakter oparty na procesie zbliżania i oddalania w społecznej przestrzeni, którego kres wyznacza stanie się albo swoim, albo też obcym-wrogim, wykluczonym z jakiejkolwiek orbity wspólnego członkostwa. Nie ma co ukrywać, iż ten ostatni przypadek przynosi zdecydowanie najgorsze konsekwencje dla ludzkości. Pytanie, które się nasuwa w tym miejscu, brzmi: co stymuluje ową zmienność w relacjach jednostki z innym człowiekiem (obcym) oraz czy można w ten proces jakoś ingerować.

\section{Model identyfikacji społecznej a „mit" Ferdinanda Tönniesa}

Analizując problem tożsamości człowieka w kontekście wielokulturowości społecznej, możemy przywołać zaproponowany przez Johna C. Turnera (1999) model identyfikacji społecznej, wyjaśniający specyfikę działań zbiorowych. Według tego autora, mówiąc o tożsamości, dotykamy poznawczego wymiaru odwołującego się do sposobów społecznej kategoryzacji rzeczywistości, a może przede wszystkim samej siebie przez osobę. Tożsamość społeczną stanowią identyfikacje jednostki opisujące ją w kategoriach przynależności grupowej. Natomiast tożsamość osobista dotyczy charakterystyk indywidualnych, jednostkowych, niewynikających z grupowego członkostwa. Można w tym podejściu dostrzec pewne analogie do propozycji Simmla, co w jakimś sensie także uzasadnia to teoretyczne nawiązanie. Zasadnicze w przywołanym modelu identyfikacji społecznej, który zdaniem Turnera opisuje proces powstawania grup społecznych, jest założenie, że musi funkcjonować jakiś mechanizm, za pomocą którego dochodzi do swoistego „przełączenia” w strukturze tożsamościowej z jednego wymiaru 
kategoryzacji do drugiego (od indywidualnego do kolektywnego i na odwrót). „Zachowanie społeczne powinno tym samym wykazywać pewną charakterystyczną zmienność, związaną z przesunięciem umiejscawiania kontroli poznawczej od tożsamości osobistej do społecznej” (Turner 1999: 153).

Ów dość „,zagadkowy” mechanizm przełączania zdaje się odpowiadać za generowanie podziałów na „my” i „oni” (obcy) - w obrębie tożsamości oraz określanie adekwatnych sposobów działania w tych okolicznościach przez jednostkę. Jeżeli zatem analizujemy problem rozwiniętych społeczeństw, które stają się coraz bardziej złożone i wewnętrznie zróżnicowane pod względem kulturowym i pojawiających się w ich ramach wewnętrznych napięć, szczególnie istotne staje się wyjaśnienie funkcjonowania przywołanego mechanizmu w strukturze tożsamościowej. Daje to nadzieję na możliwość społecznej kontroli i neutralizacji pojawiających się konfliktów w relacjach międzyludzkich i międzygrupowych.

Próbując zatem opisać funkcjonowanie omawianego mechanizmu w kontekście napiętych relacji społecznych wyrażających się w niechęci czy też wrogości wobec Innego, możemy wskazać dwa źródła owego stanu. Pierwsze związane jest z kompetencją do działania charakteryzującą jeden z elementów triady (kondycja-koncepcja-kompetencja) definiującej złożoną tożsamość człowieka (Habermas 2002; Döbert, Habermas i Nunner-Winkler 1993; Witkowski 1988). Można to określić mianem wewnętrznej (zinternalizowanej) przyczyny generującej negatywny stosunek do Innego-obcego. Stanowić to może efekt niesprzyjających rozwojowi warunków socjalizacyjnych, kiedy struktura rodziny pozbawia jednostkę zdolności do adekwatnego balansowania w odniesieniu do sytuacyjnego kontekstu, między dystansem a bliskością, jednakowością a odmiennością oraz między aktywnością a pasywnością (Döbert, Habermas i Nunner-Winkler 1993: 20-21). Tego typu kompetencje do działania zamykają człowieka w polu oddziaływań wyłącznie bodźców o charakterze kary bądź nagrody (tożsamość naturalna) lub pragmatyzmu i rutyny (tożsamość roli) (Habermas 2002; Kaniowski 1990; Witkowski 1988). Drugie źródło natomiast związane jest z pewnym rodzajem warunków i oddziaływań zewnętrznych. Możemy wymienić tu zarówno funkcjonujące w relacjach międzygrupowych stereotypy i autostereotypy, które regulują sposób kategoryzacji społecznego świata, jak i problem zmienności instytucjonalnej oraz ruchliwości społecznej (Silberstein i Seeman 1959; Bettelheim i Janowitz 1964). Oznacza to, że upowszechniane silnie wykluczające stereotypy Innego oraz zmieniająca się sytuacja życiowa człowieka związana bądź z awansem, bądź z degradacją statusową w połączeniu z dużą dynamiką zmienności instytucjonalnych 
podstaw życia zbiorowego stanowią mocny impuls mogący uruchomić ów mechanizm „przełączania” w obrębie struktury tożsamościowej. Ta moc czynnika zewnętrznego może być proporcjonalnie mniejsza, jeżeli dotyczy to jednostek, których tożsamość osobowa wyraża się w ramach kompetencji opisanych kategoriami tożsamości naturalnej czy tożsamości roli.

Dokonując pewnej syntezy założeń powyższego modelu identyfikacji społecznej oraz wskazanych źródeł odpowiadających za kształtowanie się określonego charakteru relacji międzyludzkich, należy podkreślić znaczącą rolę języka w tym procesie. Za Castellsem (2009: 62) możemy stwierdzić, że ,język, a zwłaszcza w pełni rozwinięty język, jest podstawowym atrybutem rozpoznawania siebie i ustanawiania niewidocznych granic narodowych, mniej arbitralnych niż terytorialność i mniej wyłączających niż etniczność. [...] istnieją też silne racje przemawiające za wyłanianiem się w naszych społeczeństwach nacjonalizmu opartego na języku”. Oznacza to, że obcość, wraz z zawartym w tej kategorii czynnikiem wykluczającym, jest wyrazem poczucia niepewności i zagrożenia dotyczącego kolektywnie zdefiniowanej tożsamości. Trzeba jednak pamiętać, że niestabilność instytucjonalnego otoczenia grupy oraz starania o zachowanie własnej pozycji społecznej umożliwiającej realizację potrzeb życiowych stanowią w obecnych warunkach silniejszy bodziec do odrzucania inności niż faktyczne zagrożenia z reprezentacją tej inności związane. Drugi człowiek będący przedstawicielem innej/obcej grupy w tych kryzysowych warunkach postrzegany jest przede wszystkim w kategoriach abstrakcyjnych odnoszących się do faktycznej bądź wyobrażonej tożsamości kolektywnej, co w konsekwencji ma prowadzić do wzrostu integracji wewnętrznej grupy własnej, a tym samym przywrócić poczucie bezpieczeństwa i pewność.

Szukając odpowiedzi na pytanie, dlaczego różne kryzysowe sytuacje społecznego rozchwiania skutkują zaostrzeniem relacji międzygrupowych, czyli prowadzą do tego, że Innego postrzegamy w kategoriach obcości stanowiącej zagrożenie, możemy odwołać się do związku języka z wymiarem instytucjonalnym życia społecznego. Mary Douglas w swej pracy mającej na celu wyjaśnić, Jak myślq instytucje (2011), ukazuje proces tworzenia i podtrzymywania społecznego porządku poprzez narzędzia, jakimi są kategoryzacje, którymi posługują się jednostki i zbiorowości. Moc oddziaływania na reguły życia zbiorowego, zdaniem tej autorki, mają zwłaszcza te kategorie, które są kompatybilne ze znaturalizowanym dotychczas oglądem rzeczywistości. Oznacza to, że ów proces naturalizacji czyni ową rzeczywistość oczywistą, a sens i konieczność jej istnienia stawia poza wszelkimi wątpliwościami (Douglas 2011: 102-103). Jest to, jak się wydaje, 
szczególnie istotny trop w refleksji nad problemem wrogości wobec innego powodowanej nacjonalistyczną orientacją danej społeczności.

W tym miejscu chciałbym przywołać wskazany w tytule paragrafu ten aspekt koncepcji Ferdynanda Tönniesa, który odzwierciedla, ale także utrwala mityczny sposób postrzegania źródeł tożsamości kolektywnej odnoszącej się do wspólnoty narodowej. Autor dzieli mianowicie różnorodność form organizacji życia zbiorowego na wspólnoty i stowarzyszenia, za powstanie których odpowiadają różne rodzaje ludzkiej woli. W pierwszym przypadku mamy do czynienia z „wolą naturalną”, będącą „psychologicznym odpowiednikiem ludzkiego ciała albo też zasadą jedności życia, jeśli przez życie będziemy rozumieli taką formę rzeczywistości, do której należy też myślenie” (Tönnies 1988: 123). W drugim natomiast, mówimy o „woli arbitralnej”, która ,jest tworem samego myślenia, jest czymś rzeczywistym tylko w odniesieniu do jej podmiotu - tego, który myśli [...]” (Tönnies 1988: 124). W konsekwencji wspólnotę, w tym narodową, możemy postrzegać w kategoriach naturalnego porządku, jako efekt wrodzonych pragnień i dążności do współdziałania z jednostkami nam pod tym względem podobnymi. Pojawienie się i działanie woli naturalnej przywołany autor opisuje jako proces samoistny, ewoluujący z wykorzystaniem zawartego w sobie potencjału, którego zdolność do aktywności wynika z popędowej natury człowieka (Tönnies 1988: 125-128). Tym samym ów naturalny charakter zyskuje wspólnotowy sposób zbiorowej egzystencji, a czymś koniecznym i niezbywalnym staje się tożsamość kolektywna wyrażająca przynależność i identyfikację ze wspólnotą narodową. W sytuacjach kryzysowych, przy zaniku trwałych punktów odniesienia pozwalających się samookreślić, jednostki poszukują pozbawionych wątpliwości sensu swojego istnienia kategorii i wspólnot, umożliwiających przywrócenie swoistej równowagi życiowej oraz pewnego porządku w obrębie tożsamościowej struktury. Odwołanie się do naturalnych podstaw kolektywnej tożsamości wydaje się niezmiernie ważnym czynnikiem odpowiedzialnym za „przełączenie” dokonujące się między tożsamością indywidualną a zbiorową.

Przywołana forma naturalizacji wspólnotowej formy życia zbiorowego, a także tożsamości z tym związanej, zaprezentowana przez Tönniesa jest istotna o tyle, o ile pozwala zrozumieć ów proces powstawania napięć, konfliktów i wykluczania oparty na podstawach, choć odwołujących się do natury, to jednak stricte społecznych. Przyczynia się to do blokowania rozwoju ludzkiej tożsamości do poziomu przedkonwencjonalnego bądź konwencjonalnego (Witkowski 1988). Mamy zatem do czynienia z sytuacją postrzegania świata podziałów międzygrupowych w kategoriach 
ontologicznej konieczności - a tym samym niezmienności tego faktu - lub rozpoznanej konwencjonalności, z uznaniem jej pragmatycznej słuszności. W pierwszym przypadku granice grup i tożsamości kolektywnych są poza obszarem interakcyjnych negocjacji, co gwarantuje ich stabilność i moc wykluczania. Jednostki traktują Innego/obcego w kategoriach zagrożenia podstawowych dla nich wartości, czując się tym samym zobligowane do ich skutecznej obrony. W drugi przypadku natomiast relacje międzygrupowe wyrażają poczucie koniecznej rywalizacji o rozbieżne interesy stanowiące podstawę wspólnotowej integracji. Inny/obcy może być w tych okoliczność wykluczany ze względu na jego potencjalną chęć pozyskania zasobów, dóbr w naszym poczuciu wyłącznie nam przysługujących.

Zapętlając tok powyższego wywodu, możemy w tym miejscu powrócić do koncepcji Meada, który mówi o „uczuciu wyższości” (Mead 1975: 267-269), odnoszącym się również do problemu nacjonalizmu. Jednostki mają bowiem poczucie, że z powodu przynależności do danej grupy (narodowej) uzyskują przymioty dające im przewagę nad pozostałymi grupami i ich członkami. Może to stanowić istotny argument na rzecz pozytywnej dyskryminacji swoich, a negatywnej obcych. Jednakże zdaniem Meada owo uczucie wyższości jest całkowicie słuszne, gdy „wyraża się funkcjonalnie. [...] Wyższość nie jest celem sama w sobie, jest to sposób zachowania osobowości” (Mead 1975: 268). Można zatem wnioskować, że zdaniem przywołanego autora, funkcjonalność działania i pragmatyzm pozwolą w historii społecznej na uniknięcie skrajnie negatywnych konsekwencji powodowanych nacjonalistycznymi postawami wyrażanymi przez poszczególne jednostki i grupy społeczne. Oznaczałoby to, że w kontekście „rozszerzonego doświadczenia” zarówno dla jednostki, jak i dla zbiorowości czymś korzystnym jest wychodzenie w relacjach społecznych poza granice własnej wspólnoty. Nie tylko stanowi to bowiem czynnik rozwoju, ale również poszerza zakres możliwości działania, pozyskiwania zasobów.

Czy jednak faktycznie funkcjonalność i pragmatyzm ludzkich wyborów stanowić może swoisty mechanizm zabezpieczający przed nacjonalistycznym zamknięciem w obrębie wąsko zakrojonej wspólnoty? Otóż wydaje się, że niestety jest to niewystarczające, zwłaszcza gdy napięcia kulturowe, czy wręcz konflikty, stają się poważne i generują przemoc jako strategię rozwiązywania problemów społecznych. Zróżnicowany kulturowo system społeczny ze względu na swoją dynamiczną zmienność wymaga coraz częściej etycznych podstaw umożliwiających integrację zróżnicowanych środowisk i tożsamości w ramach dzielonej wspólnie przestrzeni. „Spektrum różnic, z którymi jednostki muszą sobie radzić na płaszczyźnie prostych 
interakcji, powiększa się w wymiarze czasowym, społecznym i rzeczowym. W coraz krótszych odstępach czasu, przy coraz bardziej przelotnych kontaktach, musimy się z coraz bardziej obcymi osobami (ukształtowanymi przez całkiem inne tradycje społeczno-kulturowe) porozumieć w coraz liczniejszych i coraz bardziej specjalistycznych kwestiach (zaostrzonych jeszcze przez niezbędny zadatek zaufania do nieznanych ekspertów)” (Habermas 2009: 271). Zdaniem przywołanego w cytacie Jürgena Habermasa kluczową rolę w porządkowaniu tak schaotyzowanej przestrzeni społecznej będącej udziałem współczesnego człowieka pełni uniwersalne prawo realizujące etyczne zasady równości i godności każdego człowieka. Niemniej jednak interesuje nas w tym momencie tożsamość człowieka, która w swoim potencjale do działania zawiera kompetencje pozwalające mierzyć się z wyzwaniem wielokulturowości. Taką możliwość daje struktura tożsamościowa pozwalająca na autonomię „ja” jednostki (tożsamość „ja”), a tym samym definiująca osobę przede wszystkim w ramach tożsamości indywidualnej, a nie kolektywnej. W tym przypadku możemy mówić o swoistym zaniku różnicy między prawem a moralnością, o „nieobecności tej różnicy we własnym świecie jednostki, dzięki wyłączaniu norm poza ten świat: wówczas o tym, co moralne, mówi uniwersalna zasada o charakterze wspólnotowym, na poziomie postkonwencjonalnym” (Witkowski 1988: 199). Troskę o tożsamość człowieka i jego indywidualny rozwój, poprzez stwarzanie odpowiednich w tym celu warunków organizacji społecznej, należy więc postrzegać także w kategoriach troski o ład społeczny pozwalający na wspólnotowe życie zróżnicowanych pod względem społeczno-kulturowym jednostek i grup.

\section{Podsumowanie}

Przeprowadzone rozważania stanowią próbę opisu problemu dotyczącego rodzących się napięć i konfliktów powodowanych współistnieniem złożonych układów społeczno-kulturowych, odciskających swe piętno na tożsamości człowieka. Dzielenie wspólnej przestrzeni z Innym/obcym wymaga nieustannej negocjacji zasad tego współżycia, a w warunkach dynamicznej i o szerokim zakresie zmiany dotychczas znanych i trwałych form życia zbiorowego obawy i lęki przed ową innością nabierają szczególnie na sile. Stanowią tym samym istotny bodziec ingerujący w wewnętrzną strukturę tożsamości jednostki. Przywracanie poczucia bezpieczeństwa możemy łączyć ze zdecydowanym naciskiem społecznym na wzmocnienie, a nierzadko na dominację kolektywnego wymiaru identyfikacji człowieka. 
Należy jednak zwrócić uwagę na to, że nie każda jednostka jest w takim samym stopniu podatna na niepewność, ryzyko i utratę poczucia bezpieczeństwa. Kompetencyjny element struktury tożsamości człowieka, oparty na różnych formach zaangażowania w otaczającą rzeczywistość, można uznać za niezmiernie wartościowy wskaźnik pewnego rodzaju podatności na nacjonalistyczne ideologie mające definiować charakter relacji między „my” i „oni”.

Można to uznać za swoisty paradoks, ale opierając się na przywołanych w tekście teoretycznych argumentach, należy przyjąć, że nie tylko w interesie jednostki leży troska o własną autonomię i rozwój, lecz także w interesie wspólnoty, gdyż tylko poprzez zapewnienie dogodnych warunków jednostkowego rozwoju, co sprzyja pozyskiwaniu przez człowieka kompetencji tożsamościowych definiowanych w kategoriach postkonwencjonalności ${ }^{3}$, wspólnota jest w stanie przekazywać etyczne podstawy swojego funkcjonowania. W konsekwencji możemy uznać, że podejmowany trud społeczny w celu zwiększenia integracji określonej wspólnoty narodowej (etnicznej) wcale nie musi się opierać na procesie nasilania się działań asymilacyjnych bądź wykluczających wszelkich obcych, którzy pozostają z tą wspólnotą w stałych stosunkach.

Wielokulturowość we współczesnym świecie stanowi ogromne wyzwanie dla życia zbiorowego w postaci potrzeby kreowania nowych reguł społecznego porządku, ale także zasad związanych z ludzkim rozwojem i procesem konstruowania tożsamości. Zdecydowanie najgorszym wyborem wydaje się próba jakiejkolwiek formy powrotu do sztywnych reguł kategoryzacji, powiązanych z wręcz nieprzekraczalnymi granicami społecznych podziałów wraz z silną dominacją kolektywnych tożsamości nad jednostkowymi identyfikacjami.

\section{Literatura}

Beck U., Giddens A., Lash S. (2009), Modernizacja refleksyjna: polityka, tradycja i estetyka w porzq̨dku społecznym nowoczesności, Warszawa: Wydawnictwo Naukowe PWN. Bettelheim B., Janowitz M. (1964), Social Change and Prejudice, Including Dynamics of Prejudice, New York: Free Press of Glencoe.

${ }^{3}$ Kategoria ta, odnosząca się do teoretycznej propozycji Habermasa, określa poziom rozwoju tożsamościowego człowieka, w ramach którego kompetencje do działania jednostki dają możliwość funkcjonowania w warunkach ambiwalencji aksjonormatywnego porządku oraz własnych doświadczeń. Wyraża także gotować do działania na rzecz wspólnoty o charakterze złożonym, wielokulturowym (Witkowski 1988). 
Bokszański Z. (2005), Tożsamości zbiorowe, Warszawa: Wydawnictwo Naukowe PWN.

Castells M. (2009), Siła tożsamości, red. M. Marody, przeł. S. Szymański, Warszawa: Wydawnictwo Naukowe PWN.

Mucha J. (1992), Cooley, Warszawa: Wiedza Powszechna.

Döbert R., Habermas J., Nunner-Winkler G. (1993), Zarys socjopsychologicznej koncepcji rozwoju tożsamości „Ja”. Wprowadzenie, „Przegląd Socjologiczny” nr 42.

Douglas M. (2011), Jak myślq instytucje, Warszawa: Wydawnictwo Naukowe PWN.

Giddens A. (2001), Nowoczesność i tożsamość: „ja” i społeczeństwo w epoce późnej nowoczesności, Warszawa: Wydawnictwo Naukowe PWN.

Habermas J. (2002), Przyczynek do krytyki rozumu funkcjonalnego, Warszawa: Wydawnictwo Naukowe PWN.

Habermas J. (2009), Uwzględniajq̨c innego. Studia do teorii politycznej, Warszawa: Wydawnictwo Naukowe PWN.

Kaniowski A.M. (1990), Pojęcie tożsamości w koncepcji Habermasa (Filozoficzna genealogia i socjologiczna wykładnia koncepcji tożsamości ja), w: L. Witkowski (red.), Dyskursy rozumu. Między przemocq a emancypacjq. Z recepcji Jürgena Habermasa w Polsce, Toruń: Wydawnictwo Adam Marszałek.

Koczanowicz L. (1992), George Herbert Mead, Wrocław: Wydawnictwo Uniwersytetu Wrocławskiego.

Kwaśniewicz W. (red.) (1999), Encyklopedia socjologii, t. 2: $K-N$, Warszawa: Oficyna Naukowa.

Leszniewski T. (2008), Tożsamość jednostki w zmieniajq̨cym się społeczeństwie, Toruń: Wydawnictwo Naukowe Uniwersytetu Mikołaja Kopernika.

Mead G.H. (1932), The Philosophy of the Present, Chicago: The Open Court Company.

Mead G.H. (1975), Umysł, osobowość, społeczeństwo, Warszawa: Wydawnictwo Naukowe PWN (Biblioteka Socjologiczna).

Mucha J. (2006), Stosunki etniczne we współczesnej myślii socjologicznej, Warszawa: Wydawnictwo Naukowe PWN.

Parsons T. (2009), System społeczny, Kraków: Zakład Wydawniczy „Nomos”.

Silberstein F.B., Seeman M. (1959), Social Mobility and Prejudice, „American Journal of Sociology" nr 65(3).

Simmel G. (2005), Socjologia, Warszawa: Wydawnictwo Naukowe PWN.

Tönnies F. (1988), Wspólnota i stowarzyszenie: rozprawa o komunizmie i socjalizmie jako empirycznych formach kultury, Warszawa: PWN.

Turner J. (1999), Ku poznawczej redefinicji pojęcia „grupy społecznej”, w: I. Machaj (red.), Małe struktury społeczne, Lublin: UMCS.

Witkowski L. (1988), Tożsamość i zmiana: wstęp do epistemologicznej analizy kontekstów edukacyjnych. Rozprawy, Toruń: Uniwersytet Mikołaja Kopernika. 